the land to project very considerably between the two points. On further examination, I found that, instead of making the land trend inward to a very deep bay at Sapapali'i and Iva, as it does in reality, it had been made to extend seaward in a series of headlands. This error is perpetzated in all the maps I have seen, including Grundemann's, and that published in the Fournal des Mruseum Godeffroy, both of which are based on Wilkes's chart.

My third and last example shall be one of a different kind. In I 870 I visited an island north of Samoa known as Quiros or Gente Hermosa. 'Wilkes' expedition described it as being without a lagoon. I found it to be barely four miles in diameter, but with a deep fresh-water logoon in its centre about three miles in diameter. Now as the ring of land around this lagoon is only about one-third of a mile across, I cannot imagine how any members of the expedition could have landed without seeing the water. Such an inaccuracy as this would have been bad enough in the description of an ordinary traveller. It is inexcusable in an expedition specially fitted out for scientific observation.

S. J. WHITMEE

\section{Cook's Collections}

IN NATURE, vol, xix. p. 373 , a remark of Dr. Hamy, of Paris, is reproduced, concerning " the fate of Cook's collections in being buried in an Austrian museum." It will be of general interest to make known that, what there is in Vienna of ethno. graphical objects in relation to Cook, consists of 260 numbers, chiefly originating from Cook's third voyage. These objects were bought by order of the Emperor. Franz in the year 1806 , at the auction of the Parkinson Museum in London (previously Lever Museum), and now form part of the large ethnographical collections, which will be accessible to the public in a few years in the new; nearly completed, Imperial Natural History Museum of Vienna. This museum will become one of the greatest and most complete on the continent, uniting all mineralogical, geological, paleontological, prehistoric, anthropological, ethnographical, zoological, and botanical imperial collections of. Vienna under the charge of Prof. Hochstetter.

Royal Zoological Museum, Dresden, February 28

\section{Magnetic Storm, May 14, 1878}

THERE appears to have been a slight error in my note (vol. xix. p. 148); in the sixth line, it should read 14 th instead of $15^{\text {th. }}$.

With this exception the observations are correctly reported, and the period during which the greatest trouble was experienced in working on the Persian Gulf cable covers the time at which the magnetic storm was observed at Stonyhurst to be at its height (vol. xviii. p, 6r7).

I cannot quite agree with Mr. Preece when he suggests (vol. xix. p. 173) the advisability of recording earth-currents in Webers. Comparatively few of the readers of NATURE would appreciate the magnitude of an earth-current if expressed in those terms, while every one, I think, will understand me when I say that the earth-current passing through the line equalled that which would be produced by a certain number of cells connected to the same circuit,

The systematic observation of earth-currents in different parts of the world is no doubt very desirable, but to be of value it must be regulated and collated by some central authority. I feel convinced that if the Society of Telegraph Engineers invited assistance in this matter, and pointed out what was actually required, the appeal would be very readily responded to.

Kurrachee, February 6

Henry C. Mance

\section{Intellect in Brutes}

IF Mr. Henslow will read my letter again he will find it distinctly stated that the "several occasions" on which the leakage took place were referred to in connection with the agency of rats only. The plumber informs me that in none of the cases (four or five) was there any sign of injury to the pipe by frost. In the specimen which $I$ have, the rats have made two ineffectual attempts to perforate the lead, and have succeeded in two distinct places. Had a frost crack existed, with consequent escape of water, thiere would have been no necessity to make two fruitless attacks on the pipe elsewhere. The specimen may be seen by any one interested at the office of The Country, ryo, Strand. Metaphysicians will probably think that Mr. Henslow has stumbled into a quagmire in his discrssion of "practical" and "abstract" reasoning. Does he believe that brutes and boys in common have nothing but the faculty of "practical" reason? When a boy finds the value of $x$ in a simple equation, is he not dealing with "abstract" ideas?

ARTHUR NICOLS

I AM not opposed to Dr. Darwin's teachings, nor do I care much whether science proves that man is descended from Adam or from some extra clever race of monkeys, so long as the truth is established. In regard to the explanation given at p. 365 of the rats eating the pipe to get at the water because they "heard the water trickling," I am inclined to look at the matter in a simple matter-of-fact way, and so feel inclined to think they cut the pipe because it was somehow in their way. Lead and blocktin gas-pipes are found cut in a similar way. Now, are they cut to get at the gas? Lead waste-pipes are also often found so cut, both from the outside and inside. I happen to be a practical plumber myself, and have bad to deal with rats in many ways, but I scarcely think that "the reasoning power of the rat" in this case has been properly reasoned out.

$2 \mathrm{x}$, Renfrew Street, Glasgow, March $\mathrm{x}$ W. P. Buchan

I BELIEVE "that the reasoning faculty in man and animals differs in degree only." But I do not think Mr. Nicols" plumber's lead-pipe case (NATURE, vol. xix. p. 365) a welltested instance of rat sagacity. We have not sufficient proof that the rats gnawed the pipe for the purpose of getting at the water ; though, of course, they used the water after having come upon it. It seems more likely that they gnawed the pipe because it obstructed their tumnelling operations; else why did they cut it in two separate places? Mr. Nicols says "a rat will not drink foul water." Neither will I when I can get better, but I am afraid $I$ should need to put up with the foul if I lived in a sewer. Cambuslang

HENRY MUIRHEAD

It is somewhat difficult to understand Mr. Henslow's remarks on the above subject in NATURE, vol. xix. p. 385 . He tells us that if the dog that rang the bell to fetch the servant to let him out of a room in which he was shut up, had not been taught to ring the bell, "it would have been abstract reasoning, but it was only practical." Further on he says that brutes never acquire " abstract reasoning."

The Arctic fox, by Mr. Henslow's own showing, appears to have used "abstract reasoning," because it had never been taught to cut the line attaching the bait to the trigger of the gun before taking the bait (of which I have seen several ca-es), or to dig a trench in the snow to avoid the shot. Can Mr. Henslow be a sportsman? If so, he ought to know that in the case referred to, to pull the bait downwards out of the line of fire was the only safe way for the fox to have acted, so as to get his head out of danger. Had he used what Mr. Henslow calls "abstract reasoning"-which, I presume, means pulling the bait, not the line, to one side out of the line of fire, the fox would certainly have been shot, as the bait could not have been moved more than four or five inches from the wooden stake through which the bait-line passes.

If $\mathrm{Mr}$. Henslow really means that the fox should have shown his powers of "abstract reasoning" by going up to the line of fire between the gun and the bait, and then pulled the string until the gun went off, I think the chances of reynard's ever eating the bait would be very small indeed. I have known him do what showed equal or greater intelligence, namely, cut the bait-string, as already mentioned.

Royal Institution, February 28

Mr. Henslow, in his letter on this subject, complains that "brute reasoning is always practical, but never abstract." As an instance of what appears to me abstract reasoning in a dog, I beg to offer the following: A few years ago we had in our possession a terrier gifted with a propensity (probably instructive) for worrying the sheep that were put to graze in a field separated from our house by another field. Coming out of the house one day I observed this dog crossing the latter field, evidently intent upon a little amusement. I called him back, he obeyed; but when he came to a patch of brushwood which hid him from view, he cut straight across the field, under cover of the brushwood, to behind a hedge, and then pursued his course 